\title{
IMPROVING WINTER WHEAT YIELDS IN ORGANIC FARMING SYSTEMS THROUGH INNOVATIONS IN GREEN MANURE MANAGEMENT
}

\author{
Danguolė Nemeikšiene் ${ }^{1}$, Aušra Arlauskiené $\dot{1}^{1}$ Alvyra Šlepetiené ${ }^{2}$ \\ 1- Joniškeelis Experimental Station of the Lithuanian Research Centre for Agriculture \\ and Forestry, Joniškèlis, LT-39301 Pasvalio distr., Lithuania \\ Ph./fax: +(370) 45 38224, e-mail: joniskelio_lzi@ post.omnitel.net \\ 2- Institute of Agriculture, Lithuanian Research Centre for Agriculture and Forestry \\ Instituto av. 1, Akademija, LT-58344, Kėdainių distr., Lithuania
}

\begin{abstract}
The paper presents effect of perennial grasses (Trifolium pratense L., Medicago sativa L., $x$ Festulolium) and their aboveground mass management methods (removed from the field, mixed, mulching) as preceding crops on $N_{\text {inorg }}$ in the soil as well as on yield of winter wheat under conditions of ecological farming. Field experiments were carried out at the Joniškelis Research Station of the Lithuanian Institute of Agriculture (LIA) on an Gleyic Cambisol. Experimental evidence indicated that content of symbiotically fixed nitrogen in the biomass of legumes accounted for the largest share (61-84\%) of the total nitrogen content (208.0-298.0 kg ha$\left.{ }^{1}\right)$, accumulated in the biomass. Winter wheat grain yield significantly $(r=0.783 ; P<0.05)$ correlated with soil inorganic nitrogen content in spring. Grain yield productivity increased by $0.01 \mathrm{t} \mathrm{ha}^{-1}$ after incorporation of $1 \mathrm{~kg}$ ha $a^{-1}$ nitrogen of legume crops biomass.
\end{abstract}

Key words: ecological agriculture, green manure, legume, $N_{\text {inorg. }}$ winter wheat yield.

\section{Introduction}

The emphasis of agricultural development programs is on economical, effective and sustainable farming systems to reduce energy consumption, protect environment and providing consumers with safe quality food. The rapid spread of organic farming. Many organic farms do not conform to basic requirements, provide the whole system of selfregulation and wellness. One of the problems of organic farming system is plants supply of nutrients, inadequate utilisation of biologically nitrogen fixed (BNF) of legume. There is a lack of an innovative multi-technology.

Some researchers suggest that legumes that can support biological $\mathrm{N}_{2}$ fixation, offer a more environmentally sound and sustainable source of $N$ to cropping systems [1, 2]. Researchers have indicated that one tone of biomass of dry legumes (aboveground and underground) can approximately bind 30-40 $\mathrm{kg}$ of nitrogen from the air [3]. This is one of the main nitrogen sources in organic farms. Perennial legume grasses overtake grain legumes by nitrogen fixation from the atmosphere, increase productivity of crop rotation plants, and improve soil properties $[4,5]$. Hence, the application of biomass of perennial legumes in arable organic farming, whose area is growing, has been limited.

This article deals with application of the green mass of perennial legumes for manure by applying the mulch technology. The aboveground mass of perennial legumes is mulched in the soil surface 2-4 times during the period of vegetation: it is cut, chopped and spread in order to use the biologic nitrogen, bound by legumes more efficiently, and to save the environment from pollution [6,7]. Chopped mass of legumes is rich in nitrogen and has a property of rapid mineralization; therefore the free nitrogen is bound by intensively growing perennial grasses or is incorporated to the content of organic matters of soil [8]. The mentioned above describes how organic compounds, rich in nitrogen, are formed in soil; they have feature of slow mineralization and provide wheat with nutrients for several years or may be incorporated to a more stable content of soil organic compounds. 
Aim is to analyze effect of perennial legumes and their aboveground mass, used for the yield and green manure, on change of soil $\mathrm{N}_{\text {inorg. }}$ as well as effect on the grain yield of winter wheat under conditions of organic farming.

\section{Materials and methods}

Site and soil. Experiments were carried out during 2007-2009 at the LIA's Joniškèlis Research Station on an Endocalcari-Endohypogleyic Cambisol (CMg-n-w-can), with a texture of clay loam (clay particles $<0.002 \mathrm{~mm}$ in Ap horizon 0-30 cm make up 27.0\%), on silty clay with deeper lying sandy loam. Parental rock is limnoglacial clay on morenic clay loam at the depth of $70-80 \mathrm{~cm}$. Bulk density of the ploughlayer is $1.5 \mathrm{Mg} \mathrm{m}^{-3}$, total porosity $41-43 \%$, air-filled porosity 15-17\%. Agrochemical characteristics of the ploughlayer: $\mathrm{pH}_{\mathrm{KCl}}-6.4$, mobile $\mathrm{P}_{2} \mathrm{O}_{5}$ and $\mathrm{K}_{2} \mathrm{O}-154$ and $224 \mathrm{mg} \mathrm{kg}^{-1}$ of soil respectively, $\mathrm{N}_{\text {total }}-0.135 \%, \mathrm{C}_{\text {org }}-1.68$ $\%$. Soil and plant analyses were done at the Laboratory of Chemical Research at LIA.

Experimental design and field management. Research was conducted in the following sequence of the crop rotation: 1) barley + undersown perennial grasses, 2) perennial grasses, 3) winter wheat. Factor A: perennial grasses: 1) red clover (Trifolium pratense L.) (control, aboveground biomass removed from the field), 2) mixture of red clover and festulolium ( $\mathrm{x}$ Festulolium), 3) lucerne (Medicago sativa L.), 4) mixture of lucerne and festulolium, 5) festulolium. Factor B: management methods of aboveground biomass of perennial grasses: 1) removed from the field, 2) mixed, 3) mulching.

In the first experimental year (2007), spring barley (Hordeum vulgare L., cv. 'Ula') was undersown with perennial grasses in compliance with the experimental design: red clover (cv. 'Vyliai', at a seed rate of 7.5 million ha $^{-1}$ ), lucerne (cv. 'Birute', at a seed rate of 7.5 million $\mathrm{ha}^{-1}$ ), intergeneric hybrid festulolium (cv. 'Punia', at a seed rate of 6.2 million $\mathrm{ha}^{-1}$ ) and mixtures of both legume grasses with festulolium (seed rate ratio of legume to grass $2: 1$ ). In the first treatment (B1) of application of the aboveground biomass of perennial grasses, the grass was cut twice at the beginning of flowering: on 10062008 and 25082008 and removed from field. In the second treatment (B2), the aboveground biomass was used under mixed management: the first grass was cut at the beginning of flowering (10 06 2008) and removed from the field, the second and third cuts were taken during perennial grass inflorescence growth stage (17 07 2008, 1208 2008) and mulched on the soil surface. In the third treatment (B3), the grass was cut every 30-40 days four times (12 05 2008, 13062008 , 1107 2008, 1208 2008) and mulched on the soil surface. Aboveground biomass for green manure was cut by a self-propelled mower, equipped with a mulching device, then chopped and evenly spread on the plot. In the second half of August, the plots of all treatments were disked and 2 weeks later were ploughed at the $25 \mathrm{~cm}$ depth. Before sowing, the field was cultivated and harrowed at the same time. Winter wheat (Triticum aestivum L., cv. 'Tauras') was sown at a seed rate of $220 \mathrm{~kg} \mathrm{ha}^{-1}$. Organic wheat cultivation technology was applied.

Soil analyses. Soil samples for the determination of $\mathrm{N}_{\text {inorg }}\left(\mathrm{N}-\mathrm{NH}_{4}+\mathrm{N}-\mathrm{NO}_{3}\right)$ content were collected from the $0-30$ and 30-60 cm soil layer after resumption of wheat growth $(0804$ 2009). $\mathrm{N}_{\text {inorg }}$ was determined: $\mathrm{N}-\mathrm{NH}_{4}$ by spectrophotometric method, $\mathrm{N}-\mathrm{NO}_{3}$ by ionometric method.

Plant analyses. After each cut, the aboveground biomass of perennial grasses was weighed. To determine the root macro-fraction biomass of plants, monoliths $0.25 \times 0.25 \times 0.24 \mathrm{~m}$ in size were dug out in the plots of each treatment replicated three times [9]. The roots were washed, dried, and air-dry weight was determined. Samples of the aboveground and underground biomass were taken for the determination of dry matter (dried to a constant weight at $105^{\circ} \mathrm{C}$ ), nitrogen. Elementar analyzer "Vario EL" and "Carry 50" were used for the determination of nitrogen in plant biomass. Having determined nitrogen concentration in the biomass, we calculated the amount of nitrogen, incorporated into the soil $\left(\mathrm{kg} \mathrm{ha}^{-1}\right)$. Nitrogen 
content $\left(\mathrm{N}_{2 \text { fix }} \mathrm{kg} \mathrm{ha}^{-1}\right)$ fixed from the atmosphere in legume biomass was calculated using the method of difference according to the following formula [2]:

$$
\mathrm{N}_{2 \text { fix }}=\mathrm{N}_{\text {legumes }}-\mathrm{N}_{\text {festulolium }}
$$

The experimental data were processed by the analysis of variance and correlation-regression analysis methods using a software package "Selekcija".

\section{Results and discussion}

Nitrogen content. The content of nitrogen incorporated into the soil was significantly dependent on the species of perennial grasses and aboveground biomass management method. The soil received the highest nitrogen content with the ploughed in biomass of pure legumes (Table 1).

Table 1.

Nitrogen content, incorporated to soil together with mass (underground and aboveground) of perennial grasses

(Joniškèlis, 2008)

\begin{tabular}{|c|c|c|c|}
\hline \multirow{2}{*}{ Perennial grasses (A) } & \multicolumn{3}{|c|}{ Management methods of perennial grasses (B) } \\
\cline { 2 - 4 } & removal from field & mixed & mulching \\
\cline { 2 - 4 } & \multicolumn{3}{|c|}{$\mathbf{k ~ k ~ h a ~}^{-1}$} \\
\hline RC & 25.4 & 215.8 & 298.0 \\
\hline RC + F & 35.5 & 156.6 & 258.3 \\
\hline L & 99.5 & 208.0 & 266.6 \\
\hline L + F & 79.6 & 171.8 & 281.5 \\
\hline F & 22.5 & 63.8 & 81.4 \\
\hline
\end{tabular}

Note: $\mathrm{RC}$ - Red clover; RC+F - Red clover + festulolium; L - Lucerne; L+F - Lucerne + festulolium; F Festulolium

Cultivation of legumes in mixtures with festulolium tended to reduce the nitrogen content, incorporated into the soil. Significantly (3.2 and 3.4 times) less nitrogen was incorporated into the soil with the biomass of pure festulolium compared to red clover and lucerne, respectively.

When the aboveground biomass of red clover had been used under mixed management, the total amount of nitrogen incorporated was $215.8 \mathrm{~kg} \mathrm{ha}^{-1}$, while during the process of mulching $-298.0 \mathrm{~kg} \mathrm{ha}^{-1} \mathrm{~N}$, respectively 8.5 and 11.7 times more, compared to the plot with removed herbage. With the aboveground biomass of red clover and festulolium mixture used under mixed management and mulching, the soil received less nitrogen compared to pure red clover sward with the same management of the aboveground biomass. Lucerne, during the first year of cultivation, formed a greater root biomass, though the aboveground biomass increased more rapidly only during the second half of summer. As a result, after lucerne cultivation, the incorporated nitrogen content was lower compared to that after red clover. Moreover, the effect of the biomass management methods on the incorporated nitrogen content was different. When the aboveground biomass of lucerne had been used under mixed management, the total incorporated $\mathrm{N}$ content was $208.0 \mathrm{~kg} \mathrm{ha}^{-1}$, while in mulching treatment $266.6 \mathrm{~kg} \mathrm{ha}^{-1} \mathrm{~N}$, or respectively 2.1 and 2.7 times more than in the treatments with all herbage yield of lucerne removed from the field. Cultivation of lucerne/festulolium mixtures and use of their aboveground biomass under mixed management influenced the fact, that the soil received by $36.2 \mathrm{~kg} \mathrm{ha}^{-1}$ less nitrogen, while after mulching by $14.9 \mathrm{~kg} \mathrm{ha}^{-1}$ more compared to pure lucerne sward with the same management of the aboveground biomass. When the aboveground biomass of festulolium had been used under mixed management and mulched, the soil received $63.8 \mathrm{~kg} \mathrm{ha}^{-1}$ and $81.4 \mathrm{~kg} \mathrm{ha}^{-1}$, or 2.8 and 3.6 times more nitrogen, 
respectively, compared with the treatment with all festulolium herbage removed from the field. However, the total nitrogen, accumulated in festulolium biomass, was removed from the soil. According to summarized data, lucernes annually fix from 300 to 600, red clover - from 150 to $300 \mathrm{~kg} \mathrm{ha}^{-1}$ of symbiotic nitrogen in their total biomass [10]. According to our research data, symbiotic nitrogen content, fixed from the air by red clover was: if the aboveground mass was removed from field $-137.9 \mathrm{~kg} \mathrm{ha}^{-1}$, if mixed method was applied $-182.4 \mathrm{~kg} \mathrm{ha}^{-1}$, if mulching was applied - $191.4 \mathrm{~kg} \mathrm{ha}^{-1}$; meanwhile lucernes - respectively 206.5, 204.4 and $251.9 \mathrm{~kg} \mathrm{ha}^{-1}$. According to methods of the aboveground mass management, symbiotic nitrogen $\left(\mathrm{N}_{2}\right)$ fixation efficiency in red clover biomass was $61-83 \%$, in lucernes $-68-84 \%$. According to Hatch D.J., mulching of the aboveground mass of clover-grass led to reduction of relative part of fixed nitrogen in biomass [11].

Inorganic nitrogen. In spring, the amount of $\mathrm{N}_{\text {inorg }}$ in soil reduced in most cases, compared to its status in the autumn. The greatest reduction in $\mathrm{N}_{\text {inorg }}$ content was noted in the treatments with the highest $\mathrm{NO}_{3}$ to $\mathrm{NH}_{4}$ ratio and the highest nitrate nitrogen content in the autumn (except for the plot with incorporated mulch of lucerne and festulolium mixture. Similar research conducted in Denmark showed that mulch, incorporated into a light-textured soil increased the risk of nitrogen leaching during the autumn-winter period [12]. Tripolskaja and Šidlauskas [13] have indicated, that incorporation of red clover biomass as green manure in a sandy loam Luvisol significantly increased nitrogen leaching in spring and summer (52\%) compared to the plot without organic manure. Literature sources indicate that leached nitrogen content during autumn period depends on precipitation and on the soil type and fertility management, ranging from $4-12 \mathrm{~kg} \mathrm{ha}^{-1}$ in soil with a high clay content [14] to $30-70 \mathrm{~kg} \mathrm{ha}^{-1}$ in sandy soils [15].

In spring in the 0-30 cm soil layer, the highest $\mathrm{N}_{\text {inorg }}$ content was after red clover, lucerne, and their mixture with festulolium. (Table 2). The use of green manure increased the amount of $\mathrm{N}_{\text {inorg. }}$ With increasing $\mathrm{N}_{\text {inorg }}$ content in the topsoil layer it also increased in the deeper layer ( $\mathrm{r}$ $=0.80 ; \mathrm{P}<0.01)$. In this layer $(30-60 \mathrm{~cm}), \mathrm{N}_{\text {inorg }}$ content varied in a similar pattern to that in the topsoil layer, but the differences were higher. In this soil layer significantly lower amount of $\mathrm{N}_{\text {inorg }}$ was observed after festulolium. In cases when legumes were cultivated in mixtures with festulolium, $\mathrm{N}_{\text {inorg. }}$ had a tendency to decrease. Comparing separate perennial grasses' management methods, it was defined that if the whole aboveground mass is mulched in the soil surface, $\mathrm{N}_{\text {inorg. }}$. content significantly increase, if compared to treatment when herbage was removed from field.

Winter wheat yield. The productivity of winter wheat was significantly influenced by the pre-crops - perennial grasses as well as their aboveground biomass management method. Comparison of various perennial grasses, used as pre-crops, revealed that winter wheat grain yield was the lowest after festulolium, significantly by on average $55 \%$ or $2.92 \mathrm{t} \mathrm{ha}^{-1}$ lower compared to that after red clover (Table 3). Application of their aboveground biomass as green manure did not increase grain yield appreciably. The highest grain yield was produced when winter wheat had been cultivated after legumes. Legume/festulolium swards reduced winter wheat yield: red clover/festulolium by on average $27 \%$ or $1.45 \mathrm{t} \mathrm{ha}^{-1}$ and lucerne/festulolium by on average $27 \%$ or $1.11 \mathrm{t} \mathrm{ha}^{-1}$, compared to respective pure legume sward.

Averaged data indicated that application of all herbage of perennial grasses as green manure (mulching) significantly increased the grain yield by $16 \%$ or $0.62 \mathrm{t} \mathrm{ha}^{-1}$. When part of the aboveground biomass had been used as green manure (mixed management), the grain yield tended to increase, the increase amounted to on average $8 \%$ or $0.30 \mathrm{t} \mathrm{ha}^{-1}$, compared to the treatment where all herbage had been removed from the field. Norwegian researches suggest that with the application of green manure for mulch (legume/non-legume) no significant increase in spring barley grain yield was obtained [16], meanwhile German researchers point 
out that red clover/grass mulch significantly increased wheat grain yield by $6 \%$, compared to the treatments where all herbage had been removed from the field [7]. The efficiency of nitrogen application from legume/festulolium mulch varied from $14 \%$ to $39 \%$ with the lowest value on the coarse sandy soil [12].

Table 2.

The amount of $N_{\text {inorg }}$ in $0-30$ and $30-60 \mathrm{~cm}$ soil layer in spring depending to perennial grasses' species and their aboveground mass management methods

(Joniškèlis, 2009)

\begin{tabular}{|c|c|c|c|c|c|}
\hline \multirow{2}{*}{$\begin{array}{c}\text { Perennial } \\
\text { grasses }(A)\end{array}$} & \multirow{2}{*}{$\begin{array}{l}\text { Soil depth } \\
\quad \mathrm{cm}\end{array}$} & \multicolumn{3}{|c|}{$\begin{array}{c}\text { Management methods of perennial } \\
\text { grasses }(B)\end{array}$} & \multirow{2}{*}{$\begin{array}{l}\text { Mean for } \\
\text { factor } A\end{array}$} \\
\hline & & $\begin{array}{l}\text { removal from } \\
\text { field }\end{array}$ & mixed & mulching & \\
\hline \multirow{3}{*}{$\mathrm{RC}$} & \multicolumn{5}{|c|}{$N_{\text {inorg }} \mathrm{kg} \mathrm{ha}^{-I}$} \\
\hline & $0-30$ & 22.27 & 28.18 & 24.06 & 24.84 \\
\hline & $30-60$ & 27.00 & 32.15 & 33.20 & 30.78 \\
\hline \multirow{2}{*}{$\mathrm{RC}+\mathrm{F}$} & $0-30$ & 20.38 & 22.26 & 25.64 & 22.76 \\
\hline & $30-60$ & 22.76 & 24.45 & 24.82 & 24.01 \\
\hline \multirow{2}{*}{$\mathrm{L}$} & $0-30$ & 20.91 & 24.11 & 28.36 & 24.46 \\
\hline & $30-60$ & 25.53 & 29.67 & 35.82 & 30.34 \\
\hline \multirow{2}{*}{$L+F$} & $0-30$ & 23.55 & 25.08 & 29.53 & 26.05 \\
\hline & $30-60$ & 19.82 & 27.64 & $40.72 *$ & 29.39 \\
\hline \multirow{2}{*}{$\mathrm{F}$} & $0-30$ & 20.13 & 19.28 & 26.22 & 21.88 \\
\hline & $30-60$ & 16.96 & 17.77 & 17.89 & $17.54 * *$ \\
\hline \multirow{2}{*}{$\begin{array}{l}\text { Mean for } \\
\text { factor B }\end{array}$} & $0-30$ & 21.45 & 23.78 & $26.76 * *$ & 24.00 \\
\hline & $30-60$ & 22.41 & 26.34 & $30.49 * *$ & 26.41 \\
\hline
\end{tabular}

Note. $\mathrm{N}_{\text {inorg }}(0-30 \mathrm{~cm})-\mathrm{LSD}_{05} \mathrm{~A}=4.218, \mathrm{~B}=3.267, \mathrm{AB}=7.306 ;(30-60 \mathrm{~cm})-\mathrm{LSD}_{05} \mathrm{~A}=7.393, \mathrm{~B}=5.727$, $\mathrm{AB}=12.805$; difference $(0-30 \mathrm{~cm})-\mathrm{LSD}_{05} \mathrm{~A}=16.318, \mathrm{~B}=12.640, \mathrm{AB}=28.264 ;(30-60 \mathrm{~cm})-\mathrm{LSD}_{05} \mathrm{~A}=$ $12.089, \mathrm{~B}=9.364, \mathrm{AB}=20.939 ; *$ - significant at $\mathrm{p}<0.05, * *-$ significant at $\mathrm{p}<0.01$.

The highest winter wheat grain yield was produced when the crop had been cultivated after red clover with aboveground biomass used under mixed management or mulched. The grain yield increase was by 0.72 and $0.71 \mathrm{t} \mathrm{ha}^{-1}$ respectively, higher compared to that in the control plot. After lucerne pre-crop, the wheat grain yield was lower $\left(0.37 \mathrm{t} \mathrm{ha}^{-1}\right)$ than that after red clover. It might have been influenced by higher root biomass and its $\mathrm{C}: \mathrm{N}$ ratio. This fact influenced slower mineralization of organic matter and reduced $\mathrm{N}_{\text {inorg }}$ accumulation in the soil (except for aboveground biomass mulching), compared to red clover. After lucerne sward, the greatest wheat grain yield increase was obtained when the aboveground biomass was used for mulch.

When the aboveground biomass of red clover/festulolium was used under mixed management or mulched, the grain yield increased, but not as much as in the treatments where it was cultivated after red clover with all herbage removed from the field. When the aboveground biomass of lucerne/festulolium had been used as green manure, especially when all of it was used as mulch, the grain yield increased and was similar to that after lucerne with herbage yield removed from the field. According to statistical analysis, winter wheat productivity increased by $0.01 \mathrm{t} \mathrm{ha}^{-1}$ after incorporation of $1 \mathrm{~kg} \mathrm{ha}^{-1}$ nitrogen of legume crops biomass. 
Table 3.

The winter wheat yield (grain and straw) depending to perennial grasses' species and their aboveground mass management methods

(Joniškèlis, 2009)

\begin{tabular}{|c|c|c|c|c|c|c|c|c|}
\hline \multirow{3}{*}{$\begin{array}{c}\text { Perennial } \\
\text { grasses }(A)\end{array}$} & \multicolumn{6}{|c|}{ Management methods of perennial grasses $(B)$} & \multirow{2}{*}{\multicolumn{2}{|c|}{ Mean for factor $A$}} \\
\hline & \multicolumn{2}{|c|}{$\begin{array}{l}\text { removal from } \\
\text { field }\end{array}$} & \multicolumn{2}{|c|}{ mixed } & \multicolumn{2}{|c|}{ mulching } & & \\
\hline & $\begin{array}{c}\text { grain } \\
\text { yield } \\
t h a^{-1}\end{array}$ & $\begin{array}{c}\text { straw } \\
\text { yield } \\
t_{h a^{-1}} \\
D M\end{array}$ & $\begin{array}{l}\text { grain } \\
\text { yield } \\
t h^{-1}\end{array}$ & $\begin{array}{c}\text { straw } \\
\text { yield } \\
\text { t ha } \\
D M \\
D M\end{array}$ & $\begin{array}{l}\text { grain } \\
\text { yield } \\
t h a^{-1}\end{array}$ & $\begin{array}{c}\text { straw } \\
\text { yield } \\
\text { t ha } \\
\text { DM }\end{array}$ & $\begin{array}{l}\text { grain } \\
\text { yield } \\
\text { t }^{\text {ha }}\end{array}$ & $\begin{array}{c}\text { straw } \\
\text { yield } \\
t_{h a^{-1}} \\
D M\end{array}$ \\
\hline $\mathrm{RC}$ & 4.83 & 3.54 & 5.55 & 4.24 & 5.54 & 4.44 & 5.31 & 4.07 \\
\hline $\mathrm{RC}+\mathrm{F}$ & $3.65^{* *}$ & 2.80 & 4.10 & 3.13 & 3.82 & 2.97 & $3.86^{* *}$ & $2.97 * *$ \\
\hline $\mathrm{L}$ & 4.64 & 4.13 & 4.80 & 3.99 & 5.58 & 4.20 & 5.01 & 4.10 \\
\hline $\mathrm{L}+\mathrm{F}$ & $3.44 * *$ & 3.01 & $3.74 *$ & 2.59 & 4.51 & 3.87 & $3.90 * *$ & $3.16^{* *}$ \\
\hline $\mathrm{F}$ & $2.37 * *$ & $1.86^{* *}$ & $2.23 * *$ & $2.20 * *$ & $2.58 * *$ & 2.30 & $2.39 * *$ & $2.14 * *$ \\
\hline $\begin{array}{l}\text { Mean for } \\
\text { factor B }\end{array}$ & 3.79 & 3.07 & 4.08 & 3.23 & $4.41 * *$ & $3.56^{*}$ & 4.09 & 3.29 \\
\hline
\end{tabular}

Note: RC - Red clover; RC+F - Red clover + festulolium; L - Lucerne; L+F - Lucerne + festulolium; F Festulolium; Grain yield $-\mathrm{LSD}_{05} \mathrm{~A}=0.500, \mathrm{~B}=0.387, \mathrm{AB}=0.865$; Straw yield $-\mathrm{LSD}_{05} \mathrm{~A}=0.531, \mathrm{~B}=$ $0.643, \mathrm{AB}=1.439 ; *$ - significant at $\mathrm{p}<0.05, * *$ - significant at $\mathrm{p}<0.01$.

Winter wheat straw yield was significantly influenced by perennial grasses species and their aboveground mass management methods. Straw yield was 1.86-4.44 $\mathrm{t} \mathrm{ha}^{-1}$ and varied between variants. Festulolium and legume/festulolium swards reduced winter wheat straw yield (22-47\%), if compared to red clover. Comparing management methods of perennial grasses, it was defined that in cases all aboveground mass was used for the green manure, wheat straw yield increased, if compared to data from plots, where all yield of perennial grasses was removed.

Within sequence of crops from legumes to non-legumes, it is important to assess synchronic features of nitrogen release from remains of incorporated crops or green manure and need for nitrogen of cultivated crops [8]. Together with increase of $\mathrm{N}_{\text {inorg. }}$ content in soil, the yield of crops increases $[8,17]$. According to our research data, winter wheat grain yield significantly $(\mathrm{P}<0.05)$ correlated with soil inorganic nitrogen content. (Fig. 1). Summarized data from many research indicated that crops can assimilate 4-33\% of nitrogen from remains of legumes during the first year [3]. 


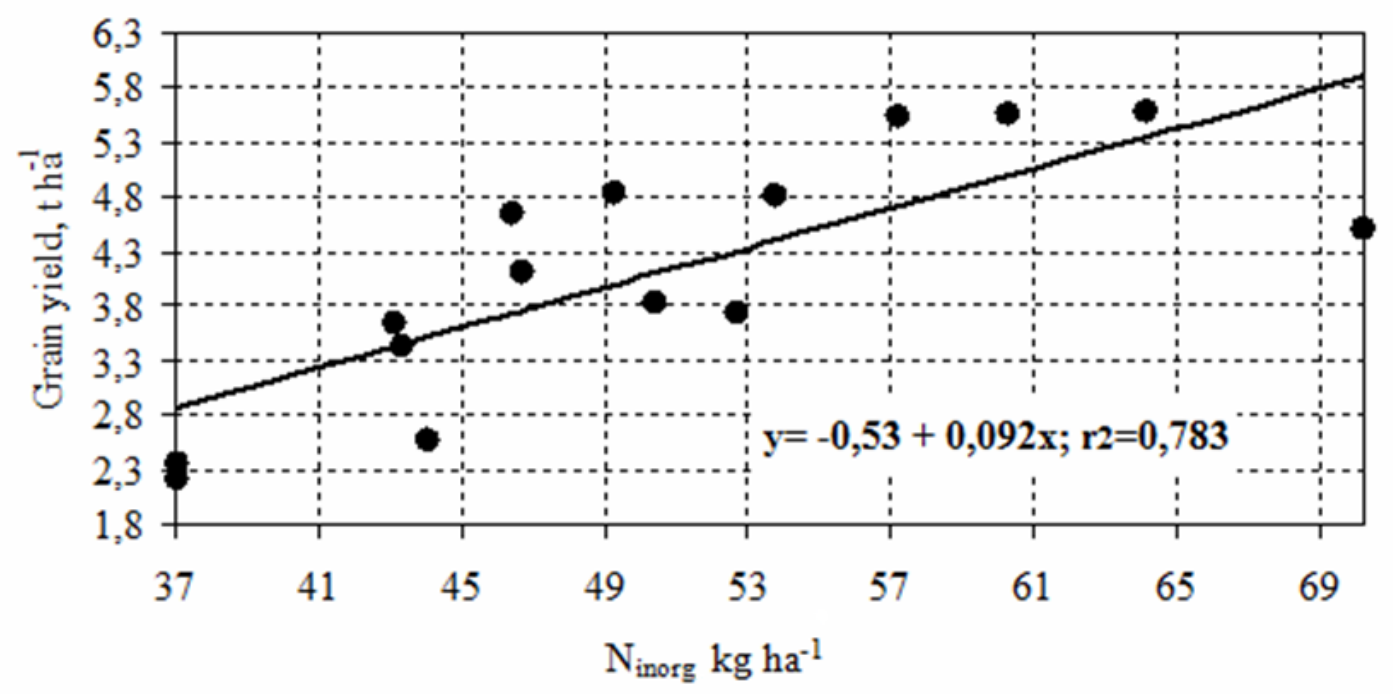

\section{Fig. 1. Grain yield relation with $\mathbf{N}_{\text {inorg }}$ content (soil layer $0-60 \mathrm{~cm}$ ) in spring after renewal of winter wheat vegetation (Joniškèlis, 2009)}

\section{Conclusions}

1. With the aboveground biomass of red clover and lucerne used under mixed management, the soil received $215.8 \mathrm{~kg} \mathrm{ha}^{-1}$ and $208.0 \mathrm{~kg} \mathrm{ha}^{-1}$ of nitrogen, respectively, while in the mulching treatments $-298.0 \mathrm{~kg} \mathrm{ha}^{-1}$ and $266.6 \mathrm{~kg} \mathrm{ha}^{-1}$, respectively. Symbiotically fixed nitrogen content in the biomass of legumes accounted for the largest share (61-84 \%) of the total nitrogen content, accumulated in the biomass.

2. In spring the highest $\mathrm{N}_{\text {inorg }}$ content was identified having used mixed management of the aboveground biomass of legumes or having mulched all biomass of legumes and that of legume/festulolium mixture. Winter wheat grain yield significantly $(\mathrm{P}<0.05)$ correlated with soil inorganic nitrogen content.

3. Winter wheat grain productivity increased by $0.01 \mathrm{t} \mathrm{ha}^{-1}$ after incorporation of $1 \mathrm{~kg} \mathrm{ha}^{-1}$ nitrogen of legume crops biomass. Festulolium and its mixtures with legumes as pre-crop reduced winter wheat grain yield, compared with red clover. Application of all aboveground biomass of perennial grasses as green manure (mulching) increased grain yield by on average $0.62 \mathrm{t} \mathrm{ha}^{-1}$; when part of the aboveground biomass had been used as green manure (mixed management) - by $0.30 \mathrm{t} \mathrm{ha}^{-1}$, compared with the treatments with herbage removed from the field.

\section{References}

1. Jensen, E. S., Hauggaard-Nielsen, H. How can increased use of biological $\mathrm{N}_{2}$ fixation in agriculture benefit the environment? Plant and Soil. vol. 252. 2003. p. 177-186.

2. Herridge, D. F., Peoples, M. B., Boddey, R. M. Global inputs of biological nitrogen fixation in agricultural systems. Plant and Soil. vol. 311. 2008. p. 1-18.

3. Peoples, M. B., Rockwell, J., Herridge, D. F. et al. The contributions of nitrogen-fixing crop legumes to the productivity of agricultural systems . Symbiosis. vol. 48. 2009. p. 1-17.

4. Watson, C. A., Atkinson, D., Gosling, P. et al. Managing soil fertility in organic farming systems. Soil Use and Management. No. 18. 2002. p. 239-247.

5. Arlauskienè,A., Maikštėnienè, S. The use of plants with different biological characteristics for accumulation of biogenic elements in soil and minimisation of filtration water pollution. Ekologija. No. 2. 2005. p. 54-65 (in Lithuanian).

6. Tripolskaja, L. Organic fertilizers and their influence on the environment. Lithuanian Institute of Agriculture, Kèdainiai. 2005. p. 205 (in Lithuanian).

7. Rinnofner, T., Friedel, J.K., de Kruijff, G., Piestch, M. G., Freyer, B. Effect of catch crops on N dynamics and following crops in organic farming. Agronomy for Sustainable Development, vol. 28. 2008. p. 551-558. 


\section{Nemeikšienė D., Arlauskienė A., Šlepetienė A. IMPROVING WINTER WHEAT YIELDS IN ORGANIC FARMING SYSTEMS THROUGH INNOVATIONS IN GREEN MANURE MANAGEMENT}

8. Crews T. E., Peoples M. B. Can the synchrony of nitrogen supply and crop demand be improved in legume and fertilizer-based agroecosystem? Nutrient Cycling in Agroecosystem. vol. 72 (2). 2005 p. 101-120.

9. Lapinskiene, N.Underground part of herbaceous plants and phytocenoses in Lithuanian. Vilnius. 1986. p. 175 (in Russian).

10. Lapinskas, E. Nitrogen chantes in the siol and its effect on plants. Lithuanian Institute of Agriculture, Kèdainiai. 2008.p. 54-59 (in Lithuanian).

11. Hatch, D.J.,Goodlass, G., Joynes, A., Shepherd, M.A.The effect of cutting, mulching and applications of farmyard manure on nitroge fixation in a red clover/grass sward . Bioresource Technology. vol. 98 (17). 2007. p. 3243-3248.

12. Olesen, E. J., Askegaard, M., Rasmussen, I. A. Winter cereal yields as affected by animal manure and green manure in organic arable farming . European Journal of Agronomy. vol. 30 (2). 2009. p. 119-128.

13. Tripolskaja, L., Šidlauskas, G. The influence of catch crops for green manure and straw on the infiltration of atmospheric precipitation and nitrogen leaching. Žemdirbystė=Agriculture. vol. 97(1).2010. p. 83-92.

14. Smith, C.J. Dunin, F.X., Zegelin, S.J., Poss, R. Nitrate leaching from a Riterine Clay soil under cereal rotation Australian Journal of Agricultural Research. vol. 49. 1998. p. 379-389.

15. Thomsen, I.K., Hansesn, J.F., Kjellerup, V., Christensen, B.T. Effect of cropping system and rates of nitrogen in animal slurry and mineral fertilizer on nitrate leaching from a sandy loam. Soil Use and Management. vol 93 (19). 1993. p. 53-57.

16. Frøseth, R. B., Hansen S., Bakken, A. K. Contribution of $\mathrm{N}$ from frequently chopped green manure to a succeeding crop of barley. Proc. of the $2^{\text {nd }}$ scientific conference of the International Society of Organic Agriculture Research ISOFAR, held at the $16^{\text {th }}$ IFOAM Organic World Congress in Cooperation with the International Federatio of Organic Agriculture Movements IFOAM „Cultivating the future based on science“. Modena, Italy, June 16-20,.2008, p. 388-398.

17. Kayser, M., Müller, J., Isselstein, J. Nitrogen management in organic farming: comparison of crop rotation residual effects on yield, $\mathrm{N}$ leaching and soil conditions. Nutrient Cycling in Agroecosystem. vol.87. 2010. p. 21-31. 